\title{
Derivational Process of Wawonii Language
}

\author{
Yuliyanah Sain ${ }^{1}$, Andi Rachmawati syarif ${ }^{2}$ \\ yuliyanahsain@yahoo.com ${ }^{1}$, rachmasyarif@gmail.com² \\ 1,2.FKIP, Universitas Muhammadiyah Kendari
}

Received: 03 May 2020 Accepted: 17 June 2020

DOI: $10.24256 /$ ideas.v8i1.1320

\begin{abstract}
This research focused on derivational process in Wawonii language at Wawonii regency. The main objective of this research was to find out derivational process of affixation in Wawonii language. This research used qualitative analysis, the data sources in this research are oral data and written data by applying some techniques of collecting data as follows: record, note taking, translation, and introspection. After the data collected the writer analyzed them through the following steps namely: making the table of the gathered data that indicate the derivational affixation in Wawonii language, the table of derivational process, making formulation and following by examples. The result of this research show that Wawonii language has derivational process of affixation consists of four affixation namely: prefix consist of four prefixes namely mon-, me-, po-, mong-, suffix consist of three suffixes namely -no, -omo, -io, confix consist of three confixes namely mo-i, pe-no, and infix consist of one infix namely -in-.
\end{abstract}

Keywords: derivational process, affixation and Wawonii language

\section{Introduction}

Wawonii as a part of South East of Sulawesi and Wawonii language is a language which has received less attention compared with neighboring language such as Wolio, Tolaki and Muna language. Nowadays, Wawonii language is still used as language in communicating such as in public area and government offices in daily life. In addition Mead (1998) stated that the language is still widely spoken by its speech community in more quest and government offices on the Wawonii Island and Menui Island. The traditional Wawonii songs and dances are still performed. On Menui Island, even the second generation of immigrants knows the local language. In addition Mead (1998) stated that, Wawonii language is a member of Bungku-Tolaki language from a lexicostatistic perspective, Wawonii occupies the central position in a language chain stretching from north Bungku to Kulisusu in the South. 
There are some researchers have conducted studies on this regional language. Berti (2005) identified twenty seven phonemes of Wawonii dialect namely twenty two consonants and five vowels, in term of morph syntax. Halwiah (2008) in her research found that Derivational Nouns of Wawonii language.

There are several reasons of doing this study. First, as the native speaker of the target language (Wawonii language) has a responsibility for improving and developing the local language (vernacular) as a part of Indonesian culture. Second, choosing the derivational affixation of Wawonii language since the writer interprets that affixation is one of important language elements should be mastered by the learners and the user of the language since it is often used in daily communication. Third, recently Wawonii language is one of subject that is studied at the Elementary school as a local load curriculum (Kurikulum Muatan Lokal).

Although, the research of Wawonii dialect has been done, nevertheless none of that above researcher discussed the derivational affixation in Wawonii language. Besides, there are still many aspects which are needed to be conducted in research and developed especially from the morphological and syntactic aspect of Wawonii language. That is why. the writer takes an initiative to do a research entitle" Derivational Process of Wawonii Language".

Wawonii language is one of the regional languages that exist in Konawe Kepulauan Regency spoken by people residing in Wawonii Island. The Wawonii Island consists of fives subs districts they are North Wawonii, South Wawonii, East Wawonii, West Wawonii, Central Wawonii. The language has some degree with other regional language of a large number of Indonesian archipelago, it has big role and function around the speech community.

Beside used a communication tool in daily life. It is also used in other activities such as in performing custom ceremony or in cultural activities this reality show that must be developed and maintained to enrich the vocabularies of Indonesian language.

Mead (1998) defined that, among variety of vernaculars there are several languages that seen to be similar such as Tolaki, Bungku, Padoe, Kulisusu, and Moronene, (for sub grouping of Bungku -Tolaki Languages) Wawonii language has also included as the member of those languages. Furthermore Mead (1998) the Wawonii language is a member of the Bungku -Tolaki language from a lexicostatistic perspective Wawonii accopies the Bungku in the North to Kulisusu in the South , he added that Wawonii is spoken on the island of Wawonii, Menui and some the mainland of southeast Sulawesi comprising two dialects Wawonii and Menui dialect. The number speaker of speaker on Wawonii island is approximately 14.000, whereas another 7.500 speakers inhibit Menui island. So, total number of the Wawonii speaker is about, 22.000 nowdays the speaker of the language approximately 40.000 speaker (taken from District Statistic Bureau)

Talking about affixes, it can not be separated from studying morphology which deals with the structure of words. It also deals with the forming and changing of word that have function and meaning. Affix is a collective form for a 
morpheme added to the base or root to form a new stem. It is subsidiary of morphemes that well known as a bound morphemes and can be embedded directly to the root consisting of one or more other morpheme. These are called a stem, that is a morpheme or combination of morpheme to which an affix can embedded. Here, this is can precede the root (prefix), can be in the middle (infix) and can be at the and of the root (suffix) (Sadar, 2006).

There are some opinions which given by the linguists about affixes. Chaer (1994) defined that affix is a form, commonly as bound morpheme, that added on a base in word formation. Furthermore, Elson et.al (1969) stated that affixes are bound morphemes which occur with root and in general, modify the basic meaning of the root in some way. In addition, Boey (1975) classified the affixes into prefixes and infixes, according to the way they combine the base or stem. Prefixes occur before the base, suffixes occur after the base, and infixes occur in the middle of the base.

The affixes can also be classified as derivational and inflection affixes, according to which base they are embedded. Derivational affixes are bound morphemes which are generally combined with the base to change part of speech class, whereas inflectional affixes are bound morphemes which carry grammatical meanings. Both derivational and inflection affixes may be used in definite word classes (Ida, 2014).

The other expert, Mc Manis, et.al (1987) stated that, the most of morphological in English is performed by affixes, that is bound morphemes usually show that are added to free morphemes. There are basically three kinds of affixes: prefixes are added to the beginning of free morpheme or other prefixes, suffixes are added to the end of free morpheme or other suffixes, and infixes are inserted into morphemes. So, affixes are bound morphemes either derivational or inflectional one that change the meaning or grammatical function of the word when they are attached to other morphemes. In addition, Hartmn et.al in Sadar (2006) stated that affix is collective term for prefix, infix and suffix added to the base or root of a word to form a new word. Furthermore, he defined that prefix is an affix which is added to the front of a root or stem e.g. un in unlucky. Infix is an affix which instead within a word. A suffix added to the of a word. It may be the plural ending $s$ in boys derivational such as kindness, happiness etc.

The term 'syntax' has been defined by many linguistics. Crystal (1991) defined that syntax as the study of the rules governing the way words are combined to form sentences in a language. In this use, syntax is opposed to morphology, the study of word structure. An alternative definition is the study of the

- a morphological process (e.g. changing the shape of a word by adding a prefix or suffix);

- a syntactic process (changing the part of speech of a word, e.g. from verb to noun);

- a semantic process (producing a new sense). 
Yuliyanah Sain Andi Rachmawati syarif, Andi Rachmawati syarif

Derivational Process of Wawonii Language

Examples of Morphological. Syntactic and Semantic Process

\begin{tabular}{|c|l|l|l|}
\hline Words & $\begin{array}{l}\text { Morphological } \\
\text { process }\end{array}$ & $\begin{array}{l}\text { Syntactic } \\
\text { process }\end{array}$ & \multicolumn{1}{c|}{ Semantic process } \\
\hline Laugh- laugher & Add suffix -ter & $\begin{array}{l}\text { change verb } \\
\text { to noun }\end{array}$ & $\begin{array}{l}\text { Produce word denoting an } \\
\text { act or an activity }\end{array}$ \\
\hline Teach- teacher & Add suffix -er & $\begin{array}{l}\text { change verb } \\
\text { to noun }\end{array}$ & $\begin{array}{l}\text { Produce word denoting an } \\
\text { agent }\end{array}$ \\
\hline Red - redness & Add suffix -ness & $\begin{array}{l}\text { change } \\
\text { adjective } \\
\text { to noun }\end{array}$ & $\begin{array}{l}\text { Produce word denoting a } \\
\text { property }\end{array}$ \\
\hline
\end{tabular}

(adapted from: Hurford, R. And Heasly, B. (1983). "Semantics: a coursebook. ")

In other example of semantic process in term of derivational such as cook (agent noun) is derived from cook (transitive verb) just a painter (agent noun) is derived from paint (transitive verb). We just happen not to have a word cooker, meaning a person of cook, in English. Cook (noun) is an example of zero-derivation. When what is apparently the 'same' word is used in two different parts of speech, as in these examples, there is usually a semantic process involved as well, i.e. a change of sense of some sort. Thus, for example open (adjective) denotes a state, whereas open (the derived intransitive verb) denotes an action the difference between states and actions is a difference in meaning, a semantic difference.

This is a clear example of the kind of semantic differences that can exist between a derived word and its source word. The differences illustrated between large and larger than found quite generally between gradable adjectives and their comparative forms.

Unfortunately, it is not always possible to describe differences in meaning between derived words and their sources in as clear terms as we could in the case of comparative adjectives derived from gradable adjectives. As a step towards developing a full account of these meaning differences, semanticists have invented a number of classificatory labels for the various kinds of derivation found in languages. These labels include such terms as 'inchoative', 'causative', and 'resultative'.

As a summary from explanation above researcher concluded the derivational process have three in main knowledge, they are morphological process, syntactical process and semantic process. Morphological process is word formation be a complex word by adding affixation. Next, syntax is the study of the principles and processes of sentences constructed in particular languages. Syntactic investigation of a given language has goal the construction of a grammar that can be viewed as a device of some sort for producing the sentences of the language under analysis. "(Noam Chomsky, Syntactic Structures, 1971). For the definition of semantic process see the example, in (la) fighting is a verb, while in (lb), fighting is a noun. But semantically, it seems that fighting in both words is describing an action. Further, the table below showed you some examples derivational process in 
morphology, syntactical and semantic process.

Table of the other Examples Derivational Process in Morphology, Syntactical and Semantic Process

\begin{tabular}{|c|r|lr|c|}
\hline Words & $\begin{array}{c}\text { Morpohologi } \\
\text { cal Process }\end{array}$ & $\begin{array}{c}\text { Syntactical } \\
\text { Process }\end{array}$ & $\begin{array}{c}\text { Semantic } \\
\text { Process }\end{array}$ \\
\hline teach-teacher & add suffix -er & $\begin{array}{c}\text { verb to } \\
\text { noun }\end{array}$ & denoting agent \\
\hline happy-happiness & add suffix & $\begin{array}{c}\text { adj. } \\
\text {-ness }\end{array}$ & To & property \\
\hline laugh-laughter & add suffix -er & $\begin{array}{c}\text { verb } \\
\text { noun }\end{array}$ & $\begin{array}{c}\text { tonoting } \\
\text { activity }\end{array}$ \\
\hline work-worker & add suffix -er & nerb & to & denoting agent \\
\hline
\end{tabular}

(adapted from: Hurford, R. And Heasly, B. (1983). "Semantics: a coursebook

\section{Method}

In this study used a descriptive qualitative method. According to Crowl (1996) Qualitative research are used to examine question that can best the answered by verbally describing, how participant, in this study perceive and interpret various aspect of their environment. In addition Ary (1972) stated that, descriptive qualitative is designed to obtain information concerning to the current status of phenomena. Based on both of the definition above, descriptive qualitative is used to describe the object (factual data and actual data).The research site of this study was at Regency of Konawe Kepulauan (Wawonii), district of north Wawonii, Munse village.

According to Saleh (2001) stated that, the term of instruments means equipment for collecting data. These researches were used the instrument as follows: tape recorder and translation

The data source of this research was conducted oral data and written data. The oral data that is traditional story as the main data collects from the informants in the field by recording. While the written data as the secondary data will take thorough translation technique if needed. It means that the informants are asked to translate a number of sentences in Wawonii language into Indonesia language. A number of sentences in translation technique have been prepared by the researcher to make easy in asking the informants. Meanwhile, the researcher in choosing the informants who are domicile in regency of Konawe Kepulauan(Wawonii) to be exact at north Wawonii Timur, Munse as the object of this research.

Furthermore, to get the data from the informants, the researcher will choose native speaker of the target language (Wawonii language). In chosen the informants the researcher pay attention to Denes's opinion (1989) stated that, there are some 
criteria are fulfilled by the informants as follows:

1. The informant at least 30 years old and maximal 60 years old

2. The informant is a native speaker.

3. The informant is health and have complete and normal organ of speech.

4. The informant have formal education

5. The informant does not often go abroad.

In collecting the data in this research, the writer pay attention to Sadar's opinion (2006) of collecting the data by applied a number of techniques as follows:

1. Record

2. Note taking

3. Translation

4. Introspection

The technique of data analysis in this research was conducted about morphological analysis. The steps are taken as follows:

1. Making classification of the gathered that indicate the derivational affixes of derivational process in Wawonii language involving; prefix, suffix and infix.

2. Analyze the meaning and function of each prefix, suffix, infix

3. Analyze the structure of Wawonii language.

Making formulation and description for the last generalization.

\section{Results}

In this part the writer tried to show and explain the derivational of affixation in Wawonii language. It is absolutely that talking about derivational words can not be separated form affixes which can be attached or embedded to a base or root of words. Therefore, the writer fulfilled the affixation process of attaching affixes to some words that can be used to make the derivational of affixation in Wawonii dialect. The result of the derivational of affixation might be seen at the table below: Table of the result of Derivational of affixation of Wawonii dialect.

\begin{tabular}{|c|c|c|c|c|c|c|c|c|c|c|}
\hline \multirow[b]{2}{*}{ No } & \multirow[b]{2}{*}{ Word } & \multirow[b]{2}{*}{$\begin{array}{l}\text { Base } \\
\text { word }\end{array}$} & \multirow{2}{*}{$\begin{array}{l}\text { Pre } \\
\text { fix }\end{array}$} & \multirow{2}{*}{$\begin{array}{l}\text { Suf } \\
\text { fix }\end{array}$} & \multirow{2}{*}{$\begin{array}{l}\text { Co } \\
\text { nfi } \\
\mathbf{X} \\
\end{array}$} & \multirow{2}{*}{$\begin{array}{l}\text { In } \\
\text { fi } \\
\text { X }\end{array}$} & \multicolumn{2}{|c|}{ Indonesian } & \multicolumn{2}{|l|}{ English } \\
\hline & & & & & & & Meaning & $\begin{array}{l}\text { Base } \\
\text { word }\end{array}$ & English & $\begin{array}{l}\text { Base } \\
\text { word }\end{array}$ \\
\hline 1. & $\begin{array}{l}\text { Mons } \\
\text { upirz }\end{array}$ & Supiri & & & & & $\begin{array}{l}\text { Mengen } \\
\text { darai }\end{array}$ & $\begin{array}{l}\text { Penge } \\
\text { ndara }\end{array}$ & Drive & Driver \\
\hline 2. & Meraha & Raha & & & & & $\begin{array}{l}\text { Membua } \\
\text { trumah }\end{array}$ & Rumah & $\begin{array}{ll}\text { Make a } \\
\text { house }\end{array}$ & House \\
\hline 3. & $\begin{array}{l}\text { wemb } \\
\text { eno }\end{array}$ & Wembe & & & & & $\begin{array}{l}\text { Kambin } \\
\text { gnya }\end{array}$ & $\begin{array}{l}\text { Kamb } \\
\text { ing }\end{array}$ & $\begin{array}{l}\text { Her/his } \\
\text { goat }\end{array}$ & Goat \\
\hline 4. & $\begin{array}{l}\text { Mepa } \\
\text { yasa }\end{array}$ & Payasa & & & & & $\begin{array}{l}\text { Bercerm } \\
\text { in }\end{array}$ & Cermin & $\begin{array}{l}\text { Lookin g } \\
\text { self in } \\
\text { the } \\
\text { mirror }\end{array}$ & Minor \\
\hline 5. & Pomp & Pekate & & & & & Memaki & Makian & Mock & Mock \\
\hline
\end{tabular}




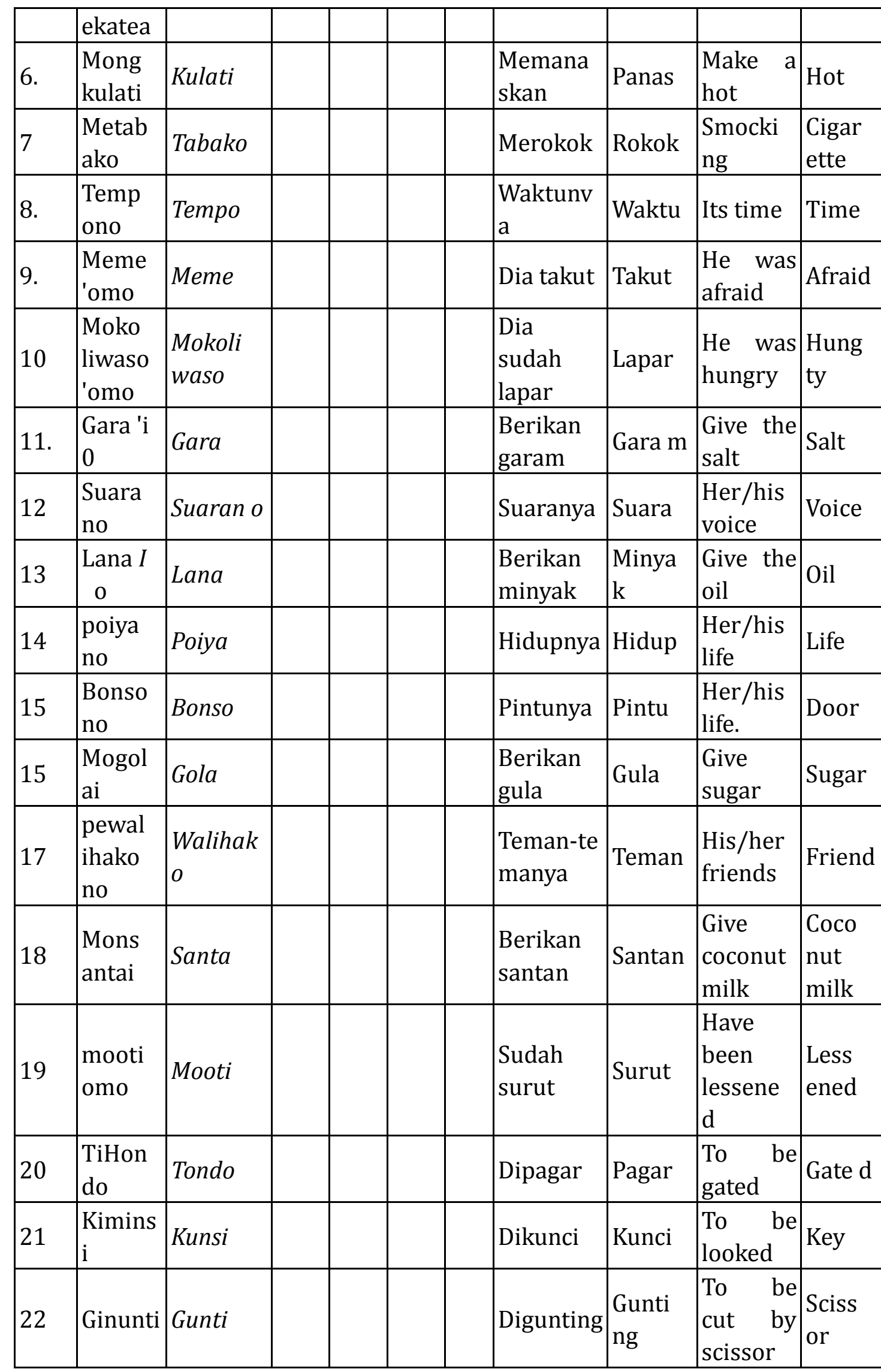

(data source from the folklore) 
From those the derivational of affixation the writer divided into fourth part namely prefix, suffix, confix and infix. (Sidu Marafad :2013)

\section{Prefixes}

According to Katamba (1993) a prefix is a morpheme which only occurs when attached to some other morpheme or morphemes such as a root or stem or base. There are four gathered in this study indicates the derivational affixes in Wawonii dialect, they are: prefix Man-, Me-, Pom-, Mong. These prefix functioned to change the lexical property, and changed the base form. Furthermore, the writer will explain each of them in the following formulation

Prefix mon-, me-, pom-, mong as derivational affixation in Wawonii dialect can be seen in the following formulation:

1. $\operatorname{supiri}(\mathrm{n})$ "driver" $\longrightarrow$ mon-+ supiri (v) "Drive"

2. raha (n)" house" $\longrightarrow$ me-+ raha (v)" Make a house"

3. payasa (n)"Mirror" $\longrightarrow$ me-+payasa (v)" looking self"

4. kulati (Adj) "hot" $\longrightarrow$ mong-+kulati (v) "memanaskan"

5. pekatae (n)"mock" $\longrightarrow$ pe-+katae (v) "mocking"

6. tabako (n)"cigarette" $\longrightarrow$ me-+tabako (v)" smocking"

The table of prefix of morphological process, syntactical process and semantic process.

\begin{tabular}{|l|l|l|l|}
\hline Words & $\begin{array}{l}\text { Morphological } \\
\text { process }\end{array}$ & $\begin{array}{l}\text { Syntactical } \\
\text { process }\end{array}$ & Semantic process \\
\hline supiri-monsupiri & Add prefix-mon & $\begin{array}{l}\text { Change noun to } \\
\text { verb }\end{array}$ & $\begin{array}{l}\text { Produce word } \\
\text { denoting act and } \\
\text { activity }\end{array}$ \\
\hline raha-meraha & Add prefix-Twe & $\begin{array}{l}\text { Change noun to } \\
\text { verb }\end{array}$ & $\begin{array}{l}\text { Produce word } \\
\text { denoting act and } \\
\text { activity }\end{array}$ \\
\hline payasa-mepayasa & Add prefix-we & & \\
\hline
\end{tabular}

\section{Suffixes}

According to Chaer (1994) suffix is affix that embedded in the end position of basic form. There are three suffixes gathered in this study indicaties the derivational suffixes in Wawonii language. namely ; no-, omo-, io,-. These prefixes, of course functioned to change noun category and adjective category to derivational verb form when they attached to a base of noun and adjective. Furthermore, the writer will explain each of them in the following formulation:
1. suara (n) +-no(pro) $\longrightarrow$ suaranya $\longrightarrow$ his voice
2. tempo (n) +-no (pro) $\longrightarrow$ waktunya $\longrightarrow$ it's time
3. meme (Adj) +-omo (adv) $\longrightarrow$ dia takut $\longrightarrow$ he is afraid
4. gara $(\mathrm{n})+-$ io $(\mathrm{v}) \longrightarrow$ berikan garam $\longrightarrow$ give the salt
5. poiya (n) +-no (pro) $\longrightarrow$ hidupnya $\longrightarrow$ his life
6. wembe (n) +-no (pro) $\longrightarrow$ kambingnya $\longrightarrow$ his goat 
The table of suffix of morphological process, syntactical process and semantic process

\begin{tabular}{|c|c|c|c|}
\hline Words & $\begin{array}{l}\text { Morphological } \\
\text { process }\end{array}$ & $\begin{array}{l}\text { Syntactical } \\
\text { process }\end{array}$ & Semantic process \\
\hline suara-suarano & Add suffix-no & $\begin{array}{l}\text { Change noun to } \\
\text { pronoun }\end{array}$ & $\begin{array}{lr}\text { produce } & \text { word } \\
\text { denoting } & \text { a } \\
\text { proverty } & \\
\end{array}$ \\
\hline tempo-tempono & Add suffix-no & $\begin{array}{l}\text { Change noun to } \\
\text { pronoun }\end{array}$ & \begin{tabular}{|lr} 
produce & word \\
denoting & a \\
proverty &
\end{tabular} \\
\hline meme-memeomo & Add suffix-omo & $\begin{array}{l}\text { Change, adjective } \\
\text { to noun }\end{array}$ & $\begin{array}{l}\text { Produce word } \\
\text { denoting } \\
\text { proverty }\end{array}$ \\
\hline gara-garaio & Add suffix-io & $\begin{array}{l}\text { Change noun to } \\
\text { verb }\end{array}$ & $\begin{array}{l}\text { Produce word } \\
\text { denoting an act or } \\
\text { and activity }\end{array}$ \\
\hline poiya-poiyano & Add suffix-no & $\begin{array}{l}\text { Change noun } \\
\text { to pronoun }\end{array}$ & $\begin{array}{l}\text { Produce denoting } \\
\text { word a Proverty }\end{array}$ \\
\hline wembe-wembeno & Add suffix-no & $\begin{array}{l}\text { Change noun } \\
\text { to pronoun }\end{array}$ & $\begin{array}{l}\text { Produce Denoting } \\
\text { word a proverty }\end{array}$ \\
\hline
\end{tabular}

\section{Confixes}

Confix is affix that is embedded both in the beginning an in the back of the basic morpheme. Chaer (1994) stated that confix is affixation that in form divisible morpheme, which the first part there is in the beginning of basic form, and the second part there, is in the end of basic form. The derivational confixes in Wawonii dialect namely: moo -omo, mo.-i, pe -no. The derivational of confixes in Wawonii language can be seen in the following formulation:

1. mo-+ koliwaso (Adj) $\longrightarrow$ mokoliwaso'omo (adj) "he was hungry"

2. mo-+ gola (n) -i $\longrightarrow$ mogola'i (v)" give the sugar"

3. mo-+ gara $(\mathrm{n})-\mathrm{i} \longrightarrow$ mogaraT $(\mathrm{v})$ " give the salt"

4. pe-+ walihako (n)-no $\longrightarrow$ pewalihakono (pro) "his/her friend"

5. mon-+ santa (n)-i monsanta'i (pro) give the coconut milk

6. mo-+oti (n) -omo $\longrightarrow$ mootiomo (n) "it has been Lessened.

The table of confix of morphological process, syntactical process and semantic 
Yuliyanah Sain Andi Rachmawati syarif, Andi Rachmawati syarif

Derivational Process of Wawonii Language

\begin{tabular}{|c|c|c|c|}
\hline Words & $\begin{array}{l}\text { Morphological } \\
\text { process }\end{array}$ & $\begin{array}{l}\text { Syntactical } \\
\text { process }\end{array}$ & Semantic process \\
\hline koliwaso-mokoliwaso & $\begin{array}{ll}\text { Add } & \text { confix-mo } \\
\text { omo. } & \end{array}$ & $\begin{array}{l}\text { Change adjective } \\
\text { to noun }\end{array}$ & $\begin{array}{l}\text { Produce word } \\
\text { with change tense } \\
\text { to new tenses }\end{array}$ \\
\hline gola-mogolai & $\begin{array}{ll}\text { Add } & \text { confix-mo } \\
i, & \end{array}$ & $\begin{array}{l}\text { Change noun to } \\
\text { verb }\end{array}$ & $\begin{array}{l}\text { Produce word } \\
\text { denoting act or an } \\
\text { activity }\end{array}$ \\
\hline gara-mogarai & Add confix-mo $i$ & $\begin{array}{l}\text { Change noun to } \\
\text { verb }\end{array}$ & $\begin{array}{l}\text { Produce word } \\
\text { denoting act or an } \\
\text { activity }\end{array}$ \\
\hline $\begin{array}{l}\text { walihako-pewalihako } \\
\text { no }\end{array}$ & $\begin{array}{l}\text { Add } \\
\text { confix-p.no }\end{array}$ & \begin{tabular}{|l} 
Change noun to \\
pronoun
\end{tabular} & \begin{tabular}{|l|}
$\begin{array}{l}\text { Produce word } \\
\text { denoting proverty }\end{array}$ \\
\end{tabular} \\
\hline santai-monsantai & Add confix-mo i & $\begin{array}{l}\text { Change noun to } \\
\text { verb }\end{array}$ & $\begin{array}{l}\text { Produce word } \\
\text { denoting act or an } \\
\text { activity }\end{array}$ \\
\hline oti-mootiomo & $\begin{array}{l}\text { Add } \text { confix-mo } \\
\text { omo. }\end{array}$ & $\begin{array}{l}\text { Change adjective } \\
\text { to noun }\end{array}$ & $\begin{array}{l}\text { Produce word } \\
\text { with change tenses } \\
\text { to now tenses }\end{array}$ \\
\hline
\end{tabular}

\section{Infixes}

According to Chaer (1994) defined that infix is an affix that embedded in the middle of basic form. Infixes are affixes which occur inside a root itself (Elson etal 1969 ). While Mc Manis et.al (1987) stated that" infixes are inserted into a morpheme. The derivational affixation of infixes in Wawonii dialect namely: - in, the derivational affixation of infix can be seen in the following formula:

1. tondo (n) "fenced " + in $\longrightarrow$ tinondo (v) " to be fenced"

2. kunsi (n) "key" + in $\longrightarrow$ kinunsi (v)" to be looked"

3. gunti (n) scissor'- in $\longrightarrow$ ginunti (v)" to be scissor"

The table of infix of morphological process, syntactical process and semantical process

\begin{tabular}{|l|l|l|l|}
\hline Words & $\begin{array}{l}\text { Morphological } \\
\text { process }\end{array}$ & Syntactical process & Semantical process \\
\hline tondo-tinondo & Add infix-m & $\begin{array}{l}\text { Change noun to } \\
\text { verb }\end{array}$ & produce activity \\
\hline kunsi-kinunsi & Add infix-m & $\begin{array}{l}\text { Change noun to } \\
\text { verb }\end{array}$ & produce activity \\
\hline gunti-ginunti & Add infix-in & $\begin{array}{l}\text { Change noun to } \\
\text { verb }\end{array}$ & produce activity \\
\hline
\end{tabular}

\section{Discussion}


In this section, the writer would like to discuss the derivational affixation in Wawonii language which would be discussing the result of interview from the native speaker in Wawonii dialect. The sources of the data are traditional story as a main data and number of sentences as secondary data, the derivational process of affixation are divided into four parts namely; prefixes suffixes, confixes and infixes.

Firstly, the derivational of prefixes in Wawonii language namely mon-, me-, pom-, mong, according to Katamba (1993) a prefix is a morpheme which only occurs when attached to some other morpheme or morphemes such as a root or stem or base. The prefixes of mon-, me-, pom-, and mong-, are derivational affixes which got form the word namely, monsupiri, meraha, mepayasa, pompekatae, mongkulati, and metabako. From the Monsupiri "Driving" is a derivational process derived from the base of noun supiri "driver ", and the word of mepayasa "bercermin " is a derivational process in Wawonii dialect derived from the base of noun payasa "mirror " meanwhile derivational process of affixation also occur in Indonesia language that is bercermin which is base is cermin and the derivational process of affixation is not occur in english and the word of Meraha " Make a house " in Wawonii dialect there is a process of derivational meraha derived from the base of noun raha means "house" and there is no derivational process of affixation in indonesian language and English, and the word Pompekatae "macking" is a derivational affixation in Wawonii dialect derived form the base of Noun pekatae" mocking", and the word of Mongkulati "boiling the water" is a derivational of affixation derived form the base of Kulati" Hot", and the word of Matabako "smocking" is a derivational of affixation derived from the base of noun tabako "cigarette" meanwhile the derivational process of affixation also accur in Indonesia language that is merokok derived from the base of noun rokok "cigarette "

Secondly, the derivational of suffixes in Wawonii dialect namely; -no, -omo, -io. According to Chaer (1994) suffix is affix that embedded in the end position of basic form. The suffixes -no, -omo, and -io, are derivational of affixation which have from wembeno. tempono, meme'omo mokolowaso'omo, gara'io and suarano. The word of wembeno is a derivational of affix derived from the base of noun wembe "goat" the derivational process just occur in Wawonii dialect and Indonesian language, in Wawonii dialect wembeno "his/her goat" and Indonesian language kambingya, and the word of tempono "its time" is a derivational of affixation derived from the base of noun tempo" its time", and the word of meme'omo is a derivational adjective affixation derived from the base of adjective meme 'afraid" and the word of mokoliwaso 'omo ' he was hungry' is a derivational affixation derived from the base of adjective mokoliwaso' hungry" there is changing of tenses of this word from present tense to ferfect tenses, and the word of gara'io "give the sugar" is derivational verb derived from the base of noun gara 'salt" and the last word is suarano " her/his voice" is derivational affixation derived from the base of noun suara "voice.

Thirdly, the derivational of confixes namely; Moo- -Omo, Mo- -i, Pe -No, 
according to Chaer (1994) confix is affixation that in form divisible morpheme, which the first part there is in the beginning of basic form, and the second part there, is in the end of basic form, the derivational of confixes in Wawonii dialect are moo- omo, mo- i, pe -no. are derivational of affixation which got from the word of mogolai, pewalihakono, monsantai, and mootiomo. Mogolai "give the sugar" is derivational verb derived from the base of noun gola "gugar", and the word of pewalihakono "her/his friends " is derivational affix derived from the base of noun pewalihako "friend" and the word of monsantai "give a coconut milk" is a derivational affixation derived from the base of noun santa "coconut milk" the derivational process in this word just occur in Wawonii dialect monsantai and does not occur in Indonesian language "berikan santan" and English "give the coconut milk" and the last is mootiomo " it has been lessened" is derivational affix derived from the base of noun oti " lessened"

And the fourtly, derivational of infixes namely: - In, according to Chaer (1994) defined that infix is an affix that embedded in the middle of basic form. Infixes are affixes which occur inside a root itself. The derivational infix in Wawonii language is -in is derivational infix which have from the words of tinondo,kinunsi, and ginunti . The word of tinondo "to be fenced "is derivational affixation derived from the base of noun tondo "fence " this word from the active word in Wawonii dialect and Indonesia language and English become passive, and the word kinunsi "to be looked" is a derivational of affixation derived from the base of noun kunsi" key" and the word of ginunti " cut with the scissor" is derivational affixation derived from the base of noun gunti "scissor ".

Lastly, the writer found that the differences between Wawonii language and English there are many examples above about the derivational of affixation did not found in English an example wembeno "her/his goat" in Wawonii dialect there is a derivational process from the base of noun wembe adding suffix no and in in English there is no derivational process of affixation it just "her/his goat. Furthermore, in Wawonii language when the native speakers talk it will eccept but when the Wawonii dialect translate into Indonesia language it does not grammatically an example Sabutono medeaho suarano ana wembe the origin translation cukupnya mendegarnya suaranya anak kambing, when we translate with a good translation it should be ketika dia mendegar suaranya itu kambing.

\section{Conclusion}

The derivational affixation of prefix consist of five of prefixes namely mon-,me-, pom-, mong-, pom. These all basic are derived from noun class and they are preceded by derivational affixation of prefixes mon-, me-, pom-, mong-, pom. The bases of all those words are nouns categories and the new word construction are verb this phenomenon proofs that prefixes in Wawonii dialect attached to noun base change it words class category become verb and the words produce class produce words denoting activity act and activity. The derivational affixation of suffix consist of three kinds of suffixes namely no, omo, io. These all basic are 
derived from noun class and they are preceded by derivational affixation of suffixes no-, omo, io. The bases all of those words are noun categories and the new words construction are pronoun and verb this phenomenon proofs that suffixes in Wawonii dialect attached to noun base change it words class category become pronoun and verb. And the words produce a words denoting activity. The derivational affixation of confix consist of three kinds of confixes namely $m o-, i$ and pe-no. These all basic are derived from adjective and noun and they are preceded by derivational affixation of confixes namely $m o-, i$ and pe-no. and the bases all of those are adjective and noun categories and the new words construction are adjective, verb and pronoun. And the words produce words denoting activity and produce words with change tenses to new tenses. The derivational affixation of infix consist of one infix namely -in .The basic words is noun and it is preceded by derivational affixation of infix -in- and the bases wors is noun and the word construction is passive. And the words produce words with change noun to passive words.

\section{References}

Alwasilah. A. C. (2003). Linguistic Umum, Pengantar Sosiologi Bahasa. Bandung : Pustaka Prima.

Andrew, C. \& McCarthy. (2002). An Introduction to English Morphology: Words and Their Structure. Edinburgh University Press.

Ba'dulu. M. A. (2019). Morphosyntax. Makassar: Badan Penerbit Universitas Negeri Makassar.

Badudu. (1977). School of Grammar. Ujung Pandang: IKIP Ujung Pandang.

Berti. (2005). The phonetic of Wawonii Dialect. Unpublished Undergraduate Thesis: Unhalu. Kendari Indonesia..

Bauer, L. (1983). English Word Formation. London: Cambridge University Press.

Choamsky, N. (1965). Aspects of the Theory of Syntax. Cambridge: Massachusetts: The MIT Press.

Crystal, D. (1980). A first dictionary of linguistics and phonetic. London: Andre Deutch.

Ellis, D. G. (1999). From Language to Communication. Lawrence Erlbaum.

Elson, B.F. \& picket B. W. (1983). Beginning Morphology and Syntax. Mexico: Summer Iinstitute of Linguistic.

Eka, D. (1994). Elements of Grammar and Mechanics of the English Language. Uyo: Samuf (Nig.) Ltd.

Fasold R \& Linton C. J. (2006). An Introduction to Language and Linguistic. New York: Cambridge University Press.

Fromkin, V, Rodman. R. \& Hyams, N. (2007). An Introduction to Language (Eighth edition). Australia: Thomson Wadsworth.

Halwiah. (2008). Derivational Noun in Wawonii Language. Unpublished Undergraduate Thesis: Unhalu. Kendari Indonesia.. 
Yuliyanah Sain Andi Rachmawati syarif, Andi Rachmawati syarif

Derivational Process of Wawonii Language

Hurford, R. et al. (1983). Semantics a Coursebook: New York. Cambridge University Press.

Ida, H. (2014). Derivational Nouns in Bajo Language at Wawonii District. Unpublished Undergraduate Thesis: Unhalu. Kendari Indonesia.

Katamba, F. (1993). Modern Linguistics Morphology. London: The Macmilan Press LTD

Keraf, G. (1984). Tata Bahasa Indonesia. Ende Flores: Nusa Indah

Lieber, R. (2009). Introduction Morphology. New York: Cambridge University Press.

Marafad, S. (2013). Mutiara Bahasa. Yogyakarta: Pustaka Pultika

Masruddin, M. (2019). Omission: Common Simple Present Tense Errors in Students' Writing of Descriptive Text. Ethical Lingua: Journal of Language Teaching and Literature, 6(1), 30-39. https://doi.org/10.30605/ethicallingua.v6i1.1114

Masruddin, M, Karmila, K. (2018). Constructing WH-Questions througn An Error Analysis at Junior High School of Indonesia. Langkawi: Journal of The Association for Arabic and English 4 (2), 123-137. DOI: http://dx.doi.org/10.31332/lkw.v4i2.852

Masruddin, M. (2018). SOME THEORIES ON LANGUAGE REVITALIZATION. IDEAS: Journal on English Language Teaching and Learning, Linguistics and Literature, 3(1). doi:https://doi.org/10.24256/ideas.v3i1.140

Mc. Manis, Carolyn D.Z. (1987). Language Files: Material for An Introduction to Language. Ohio: Advocate Publishing Group

Mead, D. (1998). The Proto Bungku Tolaki Language. Houston . Texas: Umi Company

Murfia, N. (2007). Derivational Verbs Formation in Kulisusu Language. Unpublished Undergraduate Thesis: Unhalu. Kendari Imdonesia.

Sugiono. (2010). Derivational Nouns in Tolaki Language of Konawe Dialect. Unpublished Thesis. Kenda ri Indonesia.

Tarigan. (1992). Pengajaran Analysis Kontranstif Bahasa. Bandung: Angkasa.

Verhaar, J. W. M. (1994) Pengantar Linguistik. Yogyakarta: Universitas Gadja Mada.

Yule, G. (2006). The Study of Language. An Introduction. (Third Edition). Cambridge: University Press. 